\title{
Stem cells in the skin: waste not, Wnt not
}

\author{
Laura Alonso and Elaine Fuchs ${ }^{1}$ \\ Howard Hughes Medical Institute, Laboratory of Mammalian Cell Biology and Development, The Rockefeller University, \\ New York, New York 10021, USA
}

Human disease results from loss of organ function. Whether the tissue failure results from infarction, infection, trauma, or congenital malfunction, the ideal treatment would be regrowth of a new organ or tissue to replace that which is lost or injured. Stem cell research holds the promise of developing such treatments for many life-threatening and debilitating diseases. Stem cells come in two basic types, unrestricted and restricted. Embryonic stem cells are totipotent, able to differentiate into all cell types characteristic of the species they are taken from. Adult stem cells are thought to be more restricted in their potential, functioning as the body's natural source of cells for tissue homeostasis and repair. Although it seems unlikely that adult stem cells harvested from one tissue might be reprogrammed to take on the characteristics of a different cell type, several tantalizing results have encouraged researchers to consider this possibility. Before scientists can begin to define the limits of adult stem cell plasticity, they need to understand the signals that instruct multipotent cells to self-renew and differentiate within the lineages of their resident tissues. Skin is an excellent model system in which to explore these fundamental mechanisms, because skin keratinocytes are easily accessible and are one of the few adult stem cell types that can be maintained and propagated in vitro. These cells have already been engrafted long term to replace damaged epidermis on burn patients. Now skin biologists have begun to identify some of the key steps involved in generating a functional tissue from multipotent stem cells.

The totipotency of embryonic stem (ES) cells, coupled with their ability to respond to morphogenic signals and differentiate into any desired cell fate, makes them an attractive starting place for cell replacement therapies. If stem cells derived from adult human tissues offer similar promise, this would circumvent many of the ethical and technical issues that cloud the ES cell field (Ferrari et al. 1998; Gussoni et al. 1999; Krause et al. 2001; Peterson 2002). In the past few years, researchers have claimed

${ }^{1}$ Corresponding author.

E-MAIL fuchs@rockefeller.edu; FAX (212) 327-7954.

Article and publication are at http://www.genesdev.org/cgi/doi/10.1101/ gad.1086903. that mouse brain stem cells injected into irradiated recipient mice contribute to the recovering hematopoietic system (Bjornson et al. 1999), and conversely, some transplanted bone marrow stem cells reportedly differentiate into brain cells (Mezey et al. 2000). Even in human, female cancer patients receiving bone marrow transplants from male donors were found to have differentiated cells with male chromosomes in their cerebella, leading scientists to posit that transdifferentiation of donor hematopoietic stem cells may occur in brain tissue (Weimann et al. 2003). Although enticing, the seemingly extraordinary plasticity of adult stem cells has been met by critics who suggest that the reported transdifferentiation events may have arisen from fusion of stem cells with existing differentiated cells, or from injections of heterogeneous populations of incompletely characterized stem cells, rather than true reprogramming (Terada et al. 2002; Wagers et al. 2002; Ying et al. 2002). Advocates counter that tissue injury, which is present in clinical situations requiring treatment, increases the rate at which bone-marrow-derived stem cells transdifferentiate into other cell types such as muscle and neurons (Jiang et al. 2002; LaBarge and Blau 2002). As the controversy over stem cell plasticity continues, the potential for cell fusion or deregulated transdifferentiation raises other concerns, as cancerous cells may derive from somatic stem cells (Reya et al. 2001). The contention in the adult stem cell field reflects how little is known in a rapidly moving field whose potential impact on clinical medicine is high. A major challenge over the next decade will be to identify the molecular signals that regulate stem cell self-renewal, proliferation, and differentiation.

Unless responding to injury, most adult stem cells typically divide infrequently to maintain homeostasis within their resident tissues. As a stem cell daughter commits to differentiate, it first enters a transient state of rapid proliferation (Fig. 1A). Following several cycles of division, the transiently amplifying cells withdraw from the cell cycle and execute a terminal differentiation program (Potten et al. 1979). Stem cell progeny differentiate in response to similar external and intrinsic signals experienced by their multipotent embryonic counterparts. Adult stem cells reside in specific niches. 
A

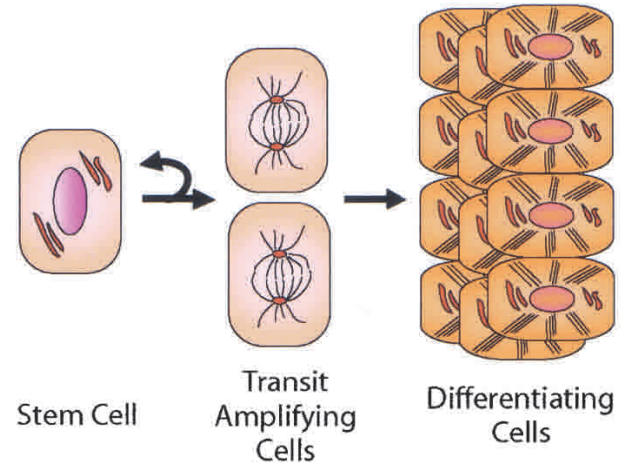

B

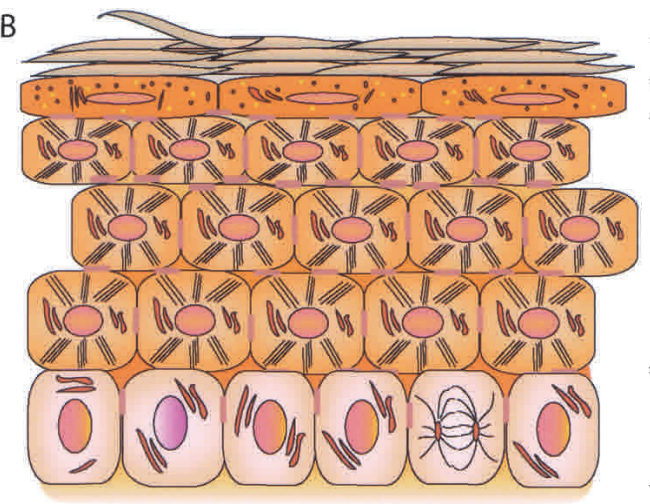

Stratum Corneum: Dead cells (squames) Granular layer: More differentiated

Spinous layer: Differentiating cells

Basal layer: Stem cells and transit amplifying cells

Figure 1. Stem cells populate a tissue. (A) Stem cells regenerate themselves and also produce transit amplifying cells, which divide and differentiate. $(B)$ Schematic of epidermal organization: transit-amplifying cells in the basal layer constantly produce progeny that move upward as they terminally differentiate and are eventually lost from the skin surface.

In some cases, the niche exposes the faces of the stem cell to different external cues, resulting in an asymmetric division. In other cases, the axis of cell division places the two daughter cells in different microenvironments. In each case, stem cells generate one daughter cell that retains the characteristics of its parent, and another that embarks on a differentiation program. Locating and analyzing stem cell niches and elucidating the molecules that orchestrate specific developmental programs will be central to determining how the environment legislates differentiation commitments and stem cell regulation.

\section{The epidermis is a rapidly self-renewing tissue}

Mammalian epidermis and its appendages (hair, nail, sebaceous and sweat glands) provide a barrier to keep harmful elements out and essential body fluids in. As the first line of defense against the various physical traumas of our environment, the epidermis must protect itself as well as the underlying tissues. The epidermis is also exposed to mutagenic ultraviolet radiation. In nonhaired or sparsely haired regions such as most human skin, the epidermis is thicker than that of furred skin, and carries the lion's share of this protective role. These constant assaults necessitate self-renewal of the epidermis, making it a prime example of an adult tissue that undergoes continual and rapid flux.

The epidermis (Fig. 1B) maintains homeostasis by constant proliferation of a single inner (basal) layer of rapidly dividing progeny of stem cells. As they withdraw from the cell cycle, the transiently amplifying cells commit to terminally differentiate, detaching from the basement membrane and initiating a trek toward the skin surface. In transit, the differentiating epidermal cells first strengthen themselves by adding to their extensive cytoskeleton of keratin filaments linked to tightly adhesive desmosomes (Fuchs and Cleveland 1998; Kowalczyk et al. 1999). Then, as they near the outer surface of the skin, they produce and secrete lipids, which organize into bilayers on a proteinaceous "cornified" envelope (for review, see Kalinin et al. 2002). Once the saran wrap seal of the body surface is complete, the epidermal cells have performed their barrier function and have no further need for metabolic activity. A process of self-destruction that resembles apoptosis ensues. Terminally differentiated cells that reach the body surface are enucleated, flattened squames that are subsequently sloughed, to be continually replaced by new cells differentiating and moving outward. Because human epidermis turns over every $2 \mathrm{wk}$, and each transiently amplifying basal cell divides only three to six times before it differentiates, the self-renewing capacity of epidermal stem cells is enormous.

Interfollicular epidermis can maintain epidermal cell replacement for extended periods of time in the absence of major injury. It contains resident stem cells, which are estimated to be situated toward the middle of a cluster of basal epidermal cells (Potten 1974; Potten and Morris 1988). This is substantiated by the fact that when human (Kolodka et al. 1998) or mouse (Mackenzie 1997) keratinocytes are genetically tagged by retroviral transduction of a LacZ gene, and then grafted onto mice, $\beta$-galactosidase expression occurs in patches.

One of the attractive features of skin epithelium is the ability to maintain and propagate skin keratinocytes in the laboratory (Rheinwald and Green 1975, 1977). Cells with remarkable proliferative potential must be present in primary human keratinocyte cultures, because the cell cultures can be passaged for hundreds of generations without undergoing senescence. Some of the colonyforming keratinocytes cultured from trypsinized human skin can generate as many as $1.7 \times 10^{38}$ progeny, far more than necessary to cover the human body (Rochat et al. 1994). Slow cycling cells in vivo are more clonogenic than actively dividing cells when placed into culture, suggesting that the most proliferative cultured cells may be stem cells (Morris and Potten 1994). The ability to maintain adult skin stem cells in vitro has allowed engraftment of cultured skin onto burn patients, a technology that stands out as one of the most successful examples of the use of adult stem cells in a clinical setting 
(Fig. 2; Green 1991). The grafted skin does not form hair follicles, but it would not be expected to do so in the absence of hair-inducing mesenchymal (dermal papilla) cells. Freshly isolated skin keratinocytes can be induced to form hair follicles when combined with isolated dermal papilla cells and implanted onto the skin of a host animal (Kishimoto et al. 2000); whether long-term keratinocyte cultures contain multipotent cells capable of producing hair follicles remains an open question.

Although the existence of skin epithelial stem cells within primary cultures is likely, finding them and studying their properties presents a more difficult challenge. These cultures are a heterogeneous mixture of putative stem cells that give rise to large colonies (holoclones), transit amplifying cells that give rise to intermediate-sized colonies (meroclones), and differentiating cells that give rise to small colonies (paraclones; Barrandon and Green 1987). Only a small percentage of primary keratinocytes give rise to holoclones. By fractionating cultured keratinocytes using fluorescence-activated cell sorting (FACS), researchers have found that cells enriched for integrins $\beta 1$ (Jones and Watt 1993) and $\alpha 6$ (Li et al. 1998; Kaur and Li 2000) have the greatest proliferative capacity in vitro. These cells also adhere differentially to extracellular matrix (ECM) components such as type IV collagen ( $\alpha 2 \beta 1$ receptor) and fibronectin ( $\alpha 5 \beta 1$ receptor), suggesting that stem cells may be retained in their niche through strong adherence to ECM-rich basement membrane (Watt 1998; Segre et al. 1999). Proteins that are less abundant in stem cells in vivo or stem-cell-derived holoclones in vitro include the transferrin receptor (Tani et

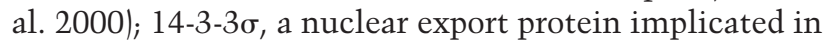
the Ras/MAPK pathway (Pellegrini et al. 2001); and the proliferation-associated transcription factor, c-myc (Gandarillas and Watt 1997).

Heterogeneity in the levels of $\beta 1$ integrin has also been observed within the basal layer of human epidermis (Jones et al. 1995; Jensen et al. 1999), suggesting that markers of holoclone-producing keratinocytes in culture may also be markers of epidermal stem cells in skin. Interestingly, integrins $\beta 1$ (Ramalho-Santos et al. 2002) and $\alpha 6$ (Ivanova et al. 2002; Ramalho-Santos et al. 2002) were also identified in screens for mRNAs whose expression is up-regulated in the transcription profiles of three different populations of stem cells compared with their transiently amplifying progeny.

Functional studies implicate several putative stem cell markers in the regulation of epidermal proliferation. Mice conditionally null for $\beta 1$ integrin exhibit impaired proliferation resulting from a defect in basement membrane assembly (Brakebusch et al. 2000; Raghavan et al. 2000). Conversely, transgenic mice expressing elevated levels of c-myc in skin stem and transit amplifying cells display epidermal hyperproliferation along with impaired wound-healing and hair loss, possibly reflecting stem cell depletion (Arnold and Watt 2001; Waikel et al. 2001). The transcription factor p63 is vital to epidermal development and is required to maintain skin epithelial stem cells (Mills et al. 1999; Yang et al. 1999). A challenge in the field is to determine the extent to which these various stem cell regulators function in maintaining stem cell character as opposed to promoting the transition between stem and transit-amplifying cells. The lack of a well-defined stem cell niche in the basal epidermal layer raises the bar on this hurdle.

\section{The hair follicle and its niche for multipotent skin stem cells: the battle of the bulge}

An appendage of mammalian epidermis, the hair follicle is composed of an outer root sheath (ORS) that is contiguous with the epidermis, an inner root sheath (IRS), and the hair shaft itself (Fig. 3A). The actively dividing, relatively undifferentiated matrix cells give rise to IRS and hair shaft. The matrix surrounds a pocket of specialized mesenchymal cells, called the dermal papilla (DP). The DP, essential to follicle formation (Oliver 1969; Jahoda et al. 1984), dictates that an appendage should be made; the characteristics of the appendage (whisker or body hair in the mouse; feather or scale in the chicken) are determined by the epithelial cells.

The lower segment of each hair follicle cycles through periods of active growth (anagen), destruction (catagen), and quiescence (telogen; Fig. 3B; Hardy 1992; Fuchs et al. 2001). In the mouse pelage, anagen lasts $\sim 3 \mathrm{wk}$, and the first three cycles are fairly synchronous. Anagen for human scalp hair can last several years, whereas the growth period for eyelashes or eyebrows is typically 1-4 mo. During anagen, matrix cells proliferate rapidly. As they move upward, they leave the cell cycle and differentiate according to a strict spatial plan, giving rise to concentric rings of the differentiated cell types of the IRS and hair shaft (Fig. 3A). During catagen, the lower follicle undergoes concerted apoptotic death. The DP moves upward

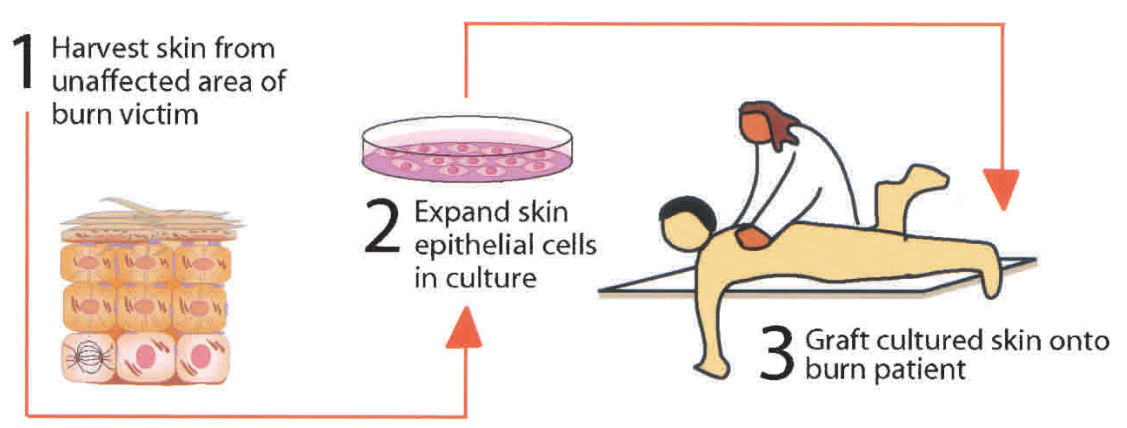

Figure 2. Skin grafting from cultured cells. Skin keratinocytes harvested from an unaffected area of the burn patient are first amplified in culture, and then grafted onto the burn to form a permanent, self-renewing skin (Green 1991). 

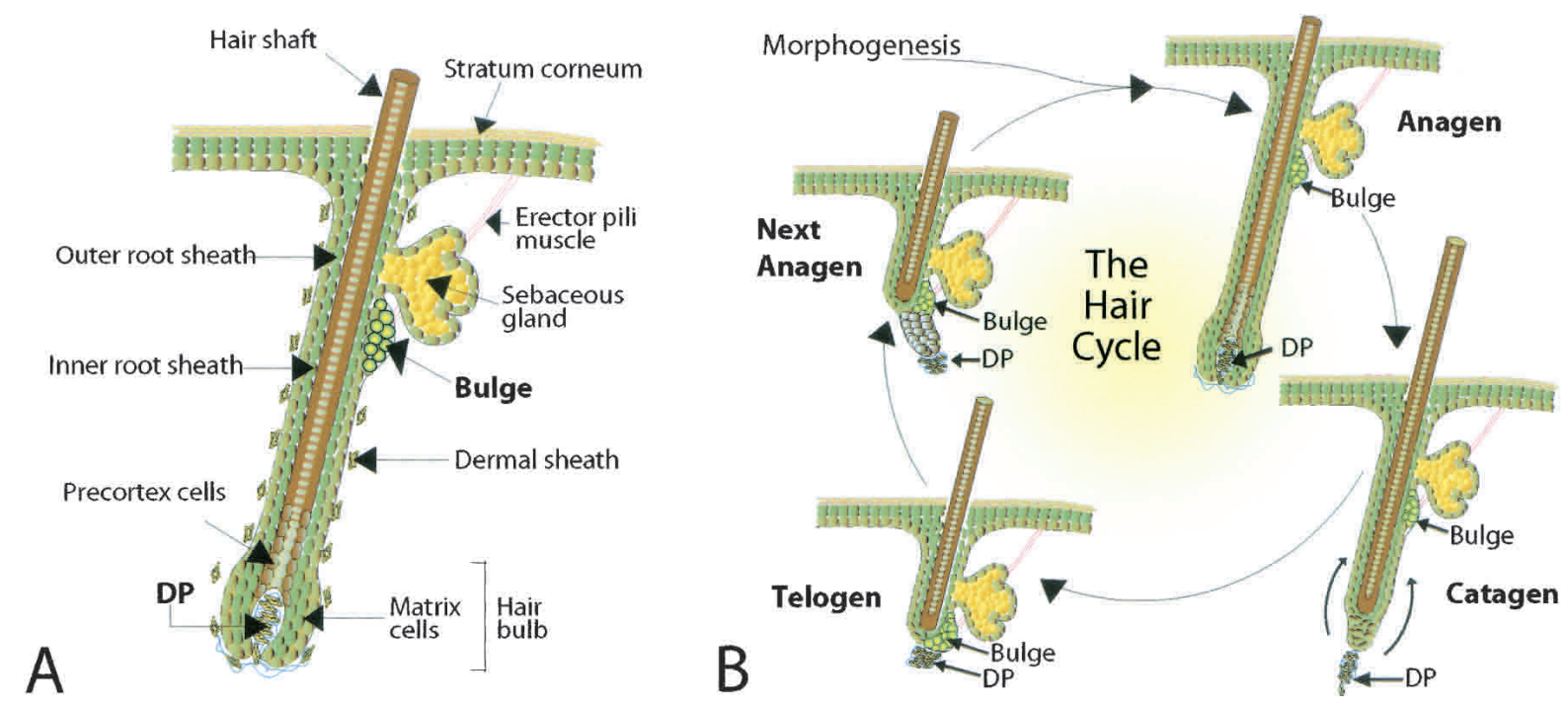

Figure 3. Schematic of an anagen $(A)$ and cycling $(B)$ hair follicle. Hair follicles undergo periodic cycling from anagen (hair producing) through catagen (regression), and into telogen (resting). (A) In the anagen hair follicle the dermal papilla (DP) is enclosed within the hair bulb, and the bulge is nestled below the sebaceous gland. (B) During the hair cycle, the proximity of the DP and the bulge varies, with the closest contact occurring at telogen as the follicle prepares for a new anagen.

until it rests beneath the bulge, where it remains during telogen. Induction of a new anagen occurs when the DP recruits one or more bulge cells to regenerate the follicle by proliferating and differentiating.

The bulge is an attractive location for skin epithelial stem cells, because it resides at the base of the permanent epithelial portion of the hair follicle, which is the deepest, most protected place within the contiguous epithelial compartment. Several lines of evidence suggest that multipotent epithelial stem cells reside in this compartment. When DP are dissected and combined with hair follicle fragments containing bulge cells, they can reconstitute a viable hair follicle when transplanted under the kidney capsule of athymic mice (Kobayashi and Nishimura 1989). Additionally, when the bulge from a normal mouse follicle is surgically replaced with bulge tissue from a mouse expressing lac $Z$ ubiquitously, the chimeric follicles have lacZ-positive cells contributing to all the lineages of the hair follicle (Oshima et al. 2001). Upon wounding or burn injury, cells from the bulge are thought to also move upward to re-epithelialize damaged epidermis (Taylor et al. 2000). Thus, bulge cells appear to be multipotent, migrating upward to generate sebaceous glands and epidermis, and downward to produce the hair follicle. Given the large numbers of hair follicles, each with a tiny stem cell compartment, the skin is a major reservoir for stem cells in the body.

When hair follicles from human or rodent skin are dissected, sectioned into pieces, and cultured in vitro, keratinocytes from the segments harboring the bulge yield the largest colonies, larger than those derived from epidermis (Kobayashi et al. 1993; Rochat et al. 1994). Bulge cells also divide only rarely; when mouse skin epithelium is briefly labeled with tritiated thymidine or BrdU and then chased for several weeks, $>95 \%$ of the retained label in skin is found in bulge cells (Cotsarelis et al. 1990; Morris and Potten 1999; Taylor et al. 2000). The label-retaining feature of bulge cells has also been used to demonstrate their multipotency. When skin epithelium is labeled with ${ }^{3} \mathrm{H}$-thymidine, then chased until most remaining label is in the bulge, and finally labeled with a second agent (BrdU), double-labeled cells presumably originating from the bulge are later found in most if not all the epithelial compartments of the skin (Taylor et al. 2000).

Given these findings, what is the relationship between the stem cells of the bulge and those residing within the basal layer of the epidermis? One possibility is that multipotent bulge cells periodically migrate from their niche to populate the basal layer of the epidermis, the matrix, and sebaceous gland. Evidence in support of bulge cell migration comes from studies on rodent whisker follicles, which initiate anagen without close bulge-DP contact (Oshima et al. 2001). In this situation, bulge cells appear to migrate down toward the DP to receive their cue to divide and differentiate. Whether bulge cells maintain their multipotency and molecular properties when they exit the niche is still largely a matter of speculation.

\section{Activating skin stem cells through Wnt and Bmp signaling}

What triggers a bulge cell to move upward or downward and execute a particular differentiation program? Although the answer to this question is still unclear, some advances have come from studies on the hair lineage. Coining the term "bulge activation hypothesis," Lavker and Sun and their coworkers postulated that a signal from the DP triggers the transition from a resting to a cycling follicle (Cotsarelis et al. 1990). Indeed, in follicles from mice lacking one of three different nuclear factors, 
"hairless," retinoid X receptor- $\alpha$, and vitamin D receptor, the DPs are left stranded in the subcutis at the end of the first postnatal hair cycle (Panteleyev et al. 1999; Li et al. 2001; Kong et al. 2002). When this happens, hair cycling and production come to a halt. This said, signals from the DP to the bulge are not sufficient on their own to activate bulge cells, because in some telogen follicles, the DP remains next to the bulge for months without activating a new hair cycle.

It seems likely that the process of activating bulge stem cells depends on factors that are both intrinsic and extrinsic to the bulge cells themselves. Surrounded by a dermal sheath that is richly innervated and vascular, the bulge dwells in a fertile milieu of input signals. An attractive model is that some environmental cue stimulates bulge cells to divide asymmetrically, replenishing the bulge stem cells and also generating daughter cells that are less adhesive to the niche. Although not yet demonstrated for skin epithelial stem cells, asymmetric divisions have been documented for some stem cells (e.g., Knoblich 2001; Lu et al. 2001; Le Borgne et al. 2002; Song and Xie 2002). In this model, a reduction in the expression of integrins or cadherins could encourage the departure of nonstem daughters from the niche. Additional cues, for example, from the DP for the hair cell fate, would then be expected to coax the cell toward a particular lineage.

What signals instruct multipotent skin cells to adopt hair follicle lineages? Insight comes from the study of two distinct regulatory events: the differentiation of adult matrix cells to become hair shaft cells, and the specification of embryonic ectodermal stem cells to produce a hair follicle. Many of the signals involved in hair follicle formation in embryonic skin are also active during the telogen-to-anagen transition, when bulge cells are induced to produce a new hair follicle (e.g., see Wang et al. 2000; Huelsken et al. 2001). Although not yet unequivocally established, it seems likely that the specifi- cation of bulge stem cells to become matrix cells will require similar signals to those involved in the recruitment of embryonic ectoderm cells to produce a hair follicle.

An early clue to the signaling involved in hair follicle lineage differentiation came from exploring the regulation of hair keratin genes. Transcriptional control regions of several hair-specific keratin genes each possesses a sequence motif that binds the Lef/Tcf family of HMG-box DNA-binding proteins (Zhou et al. 1995). Originally identified as a transcriptional regulator of $\mathrm{T}$ lymphocyte differentiation (Travis et al. 1991; van de Wetering et al. 1991; Waterman et al. 1991), Lef1 (1ymphoid enhancer factor $\underline{1}$ ) is also expressed in hair follicle matrix cells (Zhou et al. 1995; DasGupta and Fuchs 1999). Although Lef1 is found in both nuclei and cytoplasm of matrix cells, it concentrates in the nuclei of hair precursor cells (precortex) at the time when hairspecific keratin genes are induced (DasGupta and Fuchs 1999|. Lef1 is also expressed during hair embryogenesis, in ectodermal placodes as well as underlying dermal condensates (Zhou et al. 1995; DasGupta and Fuchs 1999). Elimination of Lef1 by gene targeting results in sparse hair, with a complete loss of whisker follicles and secondary follicles that account for the bulk of the hair coat (van Genderen et al. 1994). Conversely, transgenic misexpression of Lef1 in interfollicular epithelium leads to occasional ectopic hair follicles (Zhou et al. 1995). Similar in biology to hair follicles, ectopic tooth buds are found in animals misexpressing Lef1 (Zhou et al. 1995), and teeth and mammary glands are absent in Lef1 null animals (van Genderen et al. 1994).

Lef1 and its relatives are not ordinary transcription factors but, rather, DNA-binding proteins whose function is regulated by $\beta$-catenin, the downstream effector of canonical Wnt signaling (Fig. 4; for review, see Nusse 1999). In the absence of a Wnt signal, epithelial $\beta$-catenin is found in stable complexes with E-cadherin, participat-

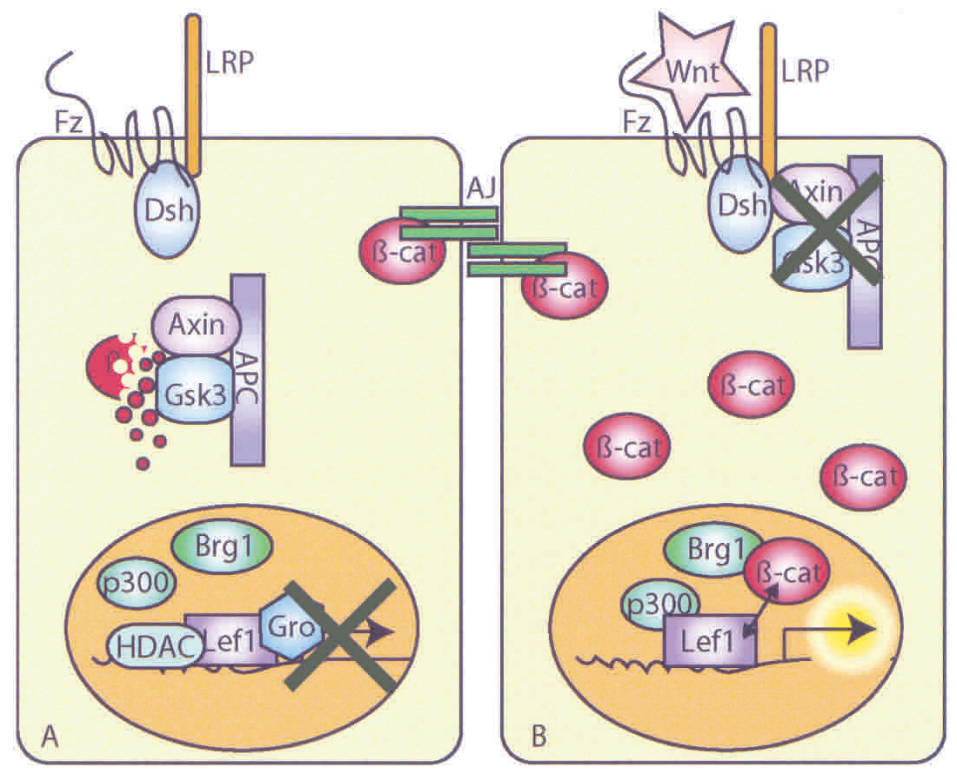

Figure 4. The canonical Wnt signaling pathway. (A) In a cell without a Wnt signal, excess $\beta$-catenin not used for AJs is degraded. $(B)$ When an extracellular Wnt binds to its receptor, $\beta$-catenin accumulates, binds to Tcf/Lef factors, and in some fashion alters gene transcription. Lef/ Tcf proteins can bind to a variety of factors that can influence chromatin-mediated repression (histone deacetylases) or activation (Brg1, p300). Exactly which Lef/Tcf complexes are recognized by $\beta$-catenin and how $\beta$-catenin influences the activity of Lef/Tcf are still a matter of debate (Molenaar et al. 1996; Tutter et al. 2001; Chan and Struhl 2002), and are likely to depend on other factors that interact with these two central proteins in the Wnt pathway. $\beta$-cat, $\beta$-catenin; Fz and LRP, Wnt receptors; Dsh, Wnt signal transducer; Axin, Gsk3, and APC, members of the $\beta$-catenin degradation complex; AJ, adherens junction; Brg1, SWI/SNF chromatin-remodeling protein; p300, $\beta$-catenin coactivator; HDAC, histone deacetylase; Gro, groucho family of repressor proteins (Povelones and Nusse 2002). 
ing in cell-cell adhesion through the formation of adherens junctions (AJs). Excess $\beta$-catenin not used in AJs is phosphorylated by a GSK-3 kinase complex and then targeted for proteosome-mediated degradation. In response to a canonical Wnt signal, however, the kinase complex is inactivated and accumulating $\beta$-catenin interacts with additional partners, such as the Lef/Tcf proteins. The intricate mechanisms of $\beta$-catenin stabilization by Wnt signals are just beginning to emerge (Povelones and Nusse 2002). It is clear that Lef/Tcfs bind to $\beta$-catenin with the same contact sites as E-cadherin (Pokutta and Weis 2002), but how exactly $\beta$-catenin leads to Lef/Tcf activation is still a matter of some debate. Lef/Tcf proteins can associate with a number of chromatin-remodeling factors, rendering repressor or activator functions (Fig. 4; Zorn et al. 1999; Labbe et al. 2000; Nishita et al. 2000; Daniels and Weis 2002). Some support the view that upon Wnt signaling, $\beta$ catenin-Lef/Tcf complexes operate as bipartite nuclear transcription factors (Molenaar et al. 1996; Tutter et al. 2001). Others favor the notion that $\beta$-catenin acts selectively on repressor forms of Lef/Tcfs, functioning either to export them from the nucleus, or to modify them cytoplasmically and then release them as competent transactivators (Chan and Struhl 2002). Irrespective of how and where the Lef/Tcf- $\beta$-catenin connection occurs, the interaction impacts directly on the status of Lef/Tcf-regulated genes. The context of Lef/Tcf DNAbinding sites within an enhancer sequence may further influence the outcome as to whether Lef1/Tcf acts as an activator or a repressor. In most situations, Wnt signaling acts to relieve repression or activate downstream target genes.

In skin, $\beta$-catenin and Lef/Tcf members are expressed in both DP and matrix cells, and both of these cell types can respond to Wnt signaling (van Genderen et al. 1994; Zhou et al. 1995; Kratochwil et al. 1996; DasGupta and
Fuchs 1999). There are at least 19 different genes encoding Wnts, 10 encoding Wnt receptors (frizzleds) and two Wnt-related lipoprotein-related proteins (LRPs) in the mouse and human genomes (Fig. 4). A number of Wnts are expressed in skin, including Wnts 3, 3a, 4, 5a, 7a, 7b, 10a, 10b, 11, and 16 (Millar et al. 1999; Reddy et al. 2001). Wnt signals have been implicated in the development of many tissues and organs, including brain, neural crest, limbs, placenta, retina, cartilage, kidney, and uterus (see Roel Nusse's Wnt Homepage at http://www.stanford. edu/ rnusse/wntwindow.html for details).

To explore the role of Wnt signaling in hair follicle development, mice have been engineered to contain a canonical Wnt reporter consisting of the $\beta$-galactosidase (GAL) coding sequence under the control of a minimal promoter and an enhancer containing multimerized Lef/ Tcf binding sites (TOP). In this system, the TOPGAL reporter is turned on when a cell containing a functionally competent Lef1/Tcf member receives a canonical Wnt signal (or equivalent). At discrete times in development, certain epithelial skin cells of transgenic TOPGAL mice express GAL, detectable by their blue coloration upon X-gal treatment (Fig. 5; DasGupta and Fuchs 1999). During early hair follicle morphogenesis, cells of the multipotent embryonic epithelium express GAL. Later in hair follicle development GAL is expressed again, in precortical cells that also express the hair keratin genes that have Lef1/Tcf-binding sites in their 5' regulatory regions (Zhou et al. 1995). In both cases, nuclear Lef1 and nuclear $\beta$-catenin appear simultaneously, consistent with the GAL expression pattern (Merrill et al. 2001).

TOPGAL activation in embryonic epithelial progenitor cells of the hair follicle suggests that multipotent skin stem cells may communicate with their environment at least in part through Wnt signals. This is supported by the complete absence of hair follicles in mice

Figure 5. Evidence for canonical Wnt signaling in skin. During embryonic development, the TOPGAL reporter gene expression is detected in the skin by a $\beta$-galactosidase activity assay (enzymatic conversion of a colorless Xgal dye to blue). The blue spots $\left(A, A^{\prime}\right)$ correspond to nascent hair follicles. The epithelial placodes are most strongly positive for $\beta$-galactosidase activity $(B)$. During the anagen phase of the hair cycle $(C-E), \beta$-galactosidase is detected in the precortex and cortex of the hair shaft $(C)$, where $\beta$-catenin $(D)$ and Lef1 $(E)$ are both nuclear. $(F)$ Mice expressing a stabilized form of $\beta$-catenin in their epidermis develop excess fur caused by postnatal hair follicle morphogenesis. CS, nuclear red counterstain; Dapi, fluorescent nuclear dye.
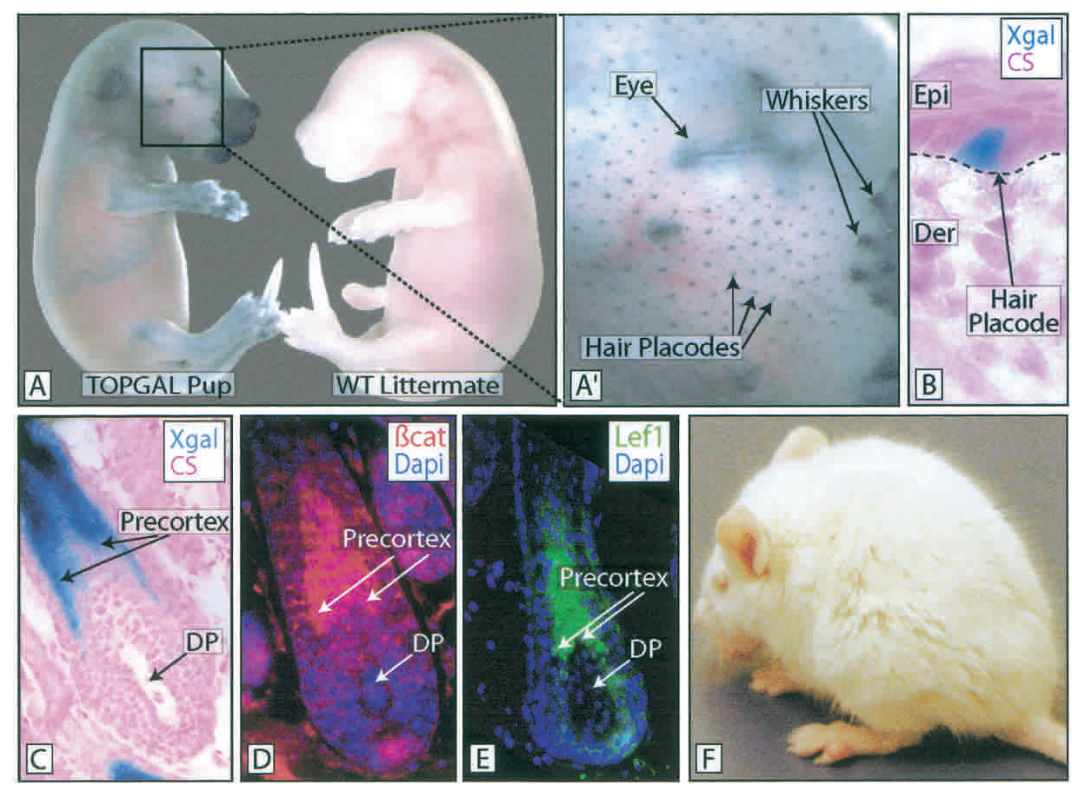
ectopically expressing the secreted Wnt inhibitor Dickkopf 1 in embryonic skin epithelial cells (Andl et al. 2002). Although the precise Wnts responsible for activating TOPGAL and hair-specific keratin genes remain to be determined, Wnts $10 \mathrm{a}$ and $10 \mathrm{~b}$ are expressed in the early follicle placode (Reddy et al. 2001), and Wnts 3, 3a, 4, 5a, 10a, 10b, and 11 are expressed within several cell diameters of the precortical cells of the developing hair follicle (Reddy et al. 2001). A functional role for Wnt signaling in hair follicle induction is supported by the phenotype of mice expressing stable $\beta$-catenin under the control of an epidermal keratin promoter/enhancer (Gat et al. 1998). These transgenic mice have excess skin epithelium, and they become very furry after the first postnatal hair cycle, resulting from de novo follicles that form in the interfollicular epidermis and ORS, where the promoter is active (Fig. 5; Gat et al. 1998). Normally, hair follicle morphogenesis occurs only in embryonic skin, raising the possibility that constitutively active $\beta$-catenin might bestow stem cell character to adult epidermal cells, expanding the stem cell population in the skin and allowing the cells to adopt hair cell as well as epidermal fates. Alternatively or additionally, stabilized $\beta$-catenin may promote hair lineage proliferation and differentiation. In this regard, it is interesting that the transgenic mice develop benign tumors composed of pure matrix and hair cells; the tumors lack epidermal, ORS, and IRS markers (Gat et al. 1998). Diagnosis of these tumors as pilomatricomas subsequently led to the identification of the genetic basis of these benign scalp tumors in humans; human pilomatricomas frequently result from stabilizing point mutations in endogenous $\beta$-catenin (Chan et al. 1999).

Wnt signaling can also maintain the hair-inducing properties of DP cells in vitro; when exposed to Wnts, DP cells in culture retain their ability to induce follicles when transplanted back into mice (Kishimoto et al. 2000). The notion that specialized dermal mesenchyme may respond to Wnts is also consistent with tissue recombination experiments, which demonstrate the requirement for both mesenchymal and epithelial Lef1 in hair development (Kratochwil et al. 1996). Bone morphogenetic protein-4 (Bmp-4), which is a potent inhibitor of feather bud formation (Jung et al. 1998; Noramly and Morgan 1998), has been reported to induce Lef1 gene expression in mouse dermal condensates in early hair follicle formation (Kratochwil et al. 1996). In contrast, mice lacking noggin, a mesenchymally expressed Bmp inhibitor, lack epithelial Lef1 expression and also lack secondary hair follicles that depend on Lef1 for their development (Botchkarev et al. 1999). Interestingly, cultured keratinocytes exposed simultaneously to Wnt3a and noggin respond by stabilizing $\beta$-catenin and Lef1, and activating a reporter gene regulated by the TOP enhancer containing multimerized Lef1-binding sites (Jamora et al. 2003). Thus, by regulating Lef1 expression, the balance of Bmps and Bmp-inhibitors may set the level of Wnt responsiveness in both mesenchymal and epithelial progenitor cells of the hair follicle. In this regard, it is interesting that the Drosophila ortholog for
Lef1, dTcf, regulates the wingless/WNT response only in the presence of DPP/BMP signals (Riese et al. 1997).

\section{Which genes are activated by Wnts and why?}

At least some of the genes regulated by Wnt signaling in the hair follicle seem to be specific to the differentiation status and location of the Wnt-receiving cell. For example, TOPGAL-positive precortical cells express hair keratin genes that are not activated in TOPGAL-positive embryonic skin cells (Kopan and Fuchs 1989). Similarly, in embryonic skin, the genes activated in TOPGAL-positive dermal condensates are likely to be different from those expressed in TOPGAL-positive ectoderm. One intriguing candidate target of Wnt signaling in embryonic skin is Eda, a TNF $\alpha$ cousin, which is essential for the formation of the primary guard hair follicles that form the mouse overcoat (Headon et al. 2001; Laurikkala et al. 2002). Guard hairs are still present in the Lef1 knockout mice, which lack Eda expression (van Genderen et al. 1994), suggesting that Lef1 might suppress the expression of some factor that can otherwise compensate for Eda.

Another recently reported downstream target for Wnt signaling is fibroblast growth factor-4 (Fgf-4), which is activated both in the developing tooth epithelium (Kratochwil et al. 2002), and in the ectoderm and underlying mesenchyme of developing limbs (Kawakami et al. 2001). In the early hair placode, Fgf signaling seems to regulate Notch/Delta signaling, as judged by the fact that Fgf mutant chicks fail to restrict the Notch ligand Delta1, normally in the dermal mesenchyme beneath the placode: the result is a loss of feather formation (Viallet et al. 1998). When Deltal is misexpressed in the ectoderm, it accelerates local placode formation while inhibiting the development of placodes in surrounding ectoderm (Crowe et al. 1998). Elevated Deltal has also been noted as a feature of human epidermal stem cells (Lowell et al. 2000).

In embryonic fly patterning, Wingless is required for production of Hedgehog, a morphogen whose mammalian homolog, Sonic hedgehog (Shh), plays a critical role in a variety of developmental processes including the hair follicle (St-Jacques et al. 1998; Chiang et al. 1999). Shh is not essential for the earliest cell fate decisions, as embryos lacking Shh have a normal number of hair buds that retain expression of Lef1, Bmp2, Bmp4, and Wnt. However, the hair buds of Shh-null embryos have a severe defect in proliferation and/or migration, and fail to develop into follicles. Gli2 seems to be the downstream effector in this process, as Gli2-null embryos phenocopy Shh-null mice, and activated Gli2 promotes proliferation in Shh-null skin (Mill et al. 2003). Gli2 may mediate its mitogenic effect by transcriptional activation of cyclins D1 and D2 in developing hair follicles (Mill et al. 2003).

In addition to influencing proliferation, epithelial cells must remodel their intercellular contacts with their neighbors to respond to external cues and grow downward to form a hair follicle. In early hair placode development, E-cadherin is down-regulated in ectodermal 
stem cells coincident with these events. The reduction in E-cadherin expression is required for follicle formation, and appears to be regulated at least in part by a complex regulatory element within the E-cadherin promoter that contains a Lef1-binding site adjacent to a binding site for the Snail family of repressor proteins (Jamora et al. 2003 and references therein).

Figure 6 lists some additional candidate Wnt target genes that might be relevant to the overall process of hair follicle morphogenesis. With the upstream and downstream involvement of so many different signaling pathways, it will take considerable time and effort to sift through the roles of Wnt signaling in orchestrating the commitment of multipotent epithelium to hair follicle fate.

What does all this mean for the stem cells in the skin? During the postnatal hair cycle, TOPGAL is activated at the beginning of anagen, when bulge cells respond to the DP. Bulge cells don't usually express Lef1, but they express Tcf3, which appears to act as a repressor rather than an activator (Merrill et al. 2001). When bulge cells differentiate to matrix cells, Tcf3 is lost and Lef1 expression is induced (DasGupta and Fuchs 1999; Merrill et al. 2001). This switch, presumably in conjunction with receipt of a Wnt signal, appears to be essential for the commitment of stem cells to a hair lineage fate. When the effect of Wnt signaling is blocked, either by conditional ablation of $\beta$-catenin or by transgenic expression of a

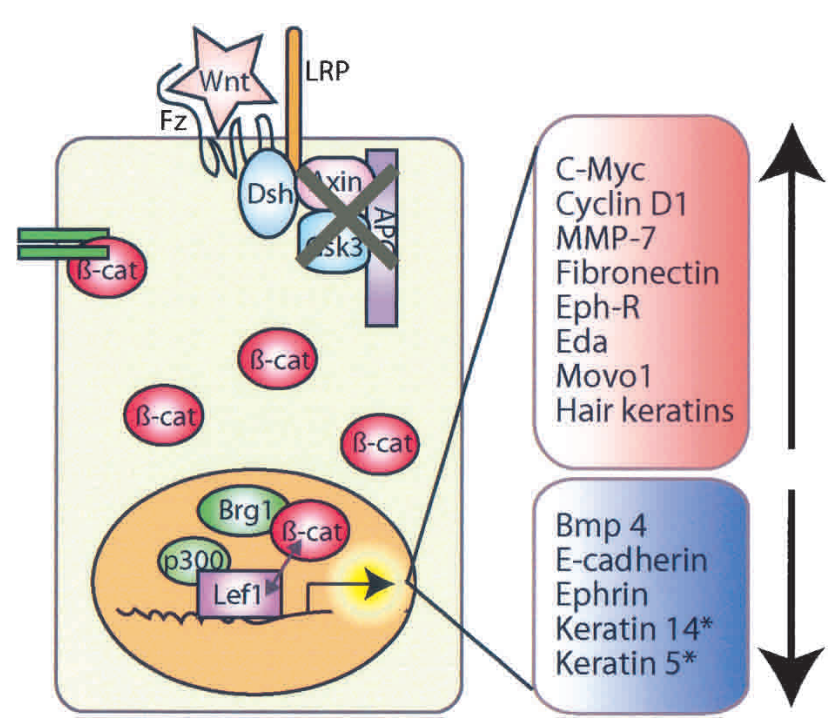

Figure 6. Wnt target genes that may act in the hair follicle. Several Wnt target genes have been reported, and some are good candidates to be involved in hair follicle morphogenesis. These include c-myc (He et al. 1998) and cyclin D1 (Tetsu and McCormick 1999) proliferation factors; MMP-7, matrix metalloproteinase 7 (Brabletz et al. 1999); Ephrin and its receptor Eph-R (Batlle et al. 2002); Eda, a Tnf family member (Laurikkala et al. 2002); Movo1, nuclear zinc finger protein ( $\mathrm{Li}$ et al. 2002); and Bmp 4, bone morphogenetic protein 4 (Baker et al. 1999). Genes that are known to be down-regulated in the matrix cells during follicle morphogenesis, but have not been reported as Wnt targets are indicated by *. truncated form of Lef1 unable to associate with $\beta$-catenin, hair formation is blocked (Huelsken et al. 2001; Merrill et al. 2001; Niemann et al. 2002). The degree to which the signaling is impaired seems to affect the outcome; sebocyte fate results from milder interference and epidermal differentiation results when signaling is blocked entirely. These and other findings increasingly suggest that the levels of $\beta$-catenin interacting partners may influence the particular lineage stem cells choose.

How might the transition from stem cell to transitamplifying cell be controlled? The key regulatory genes in the bulge are not yet known; however, attractive candidates for Tcf3-mediated repression are c-Myc and cyclin D1, which are known Wnt target genes (He et al. 1998; Tetsu and McCormick 1999|. As matrix cells are formed and switch from Tcf3 to Lef1 expression, these cell cycle genes might be activated, providing a mechanism for the conversion from the slow-cycling stem cell to the transiently amplifying progeny. This model is particularly attractive given that elevated c-Myc expression in mice results in depletion of skin stem cells (Arnold and Watt 2001; Waikel et al. 2001).

\section{Wnt signaling in other stem cells}

As outlined above, studies on the hair follicle point to a delicate precision of Wnt signaling, in which a range of cell lineage outcomes result from dose-dependent alterations in pathway members. This sensitivity is confirmed by a recent study of murine embryonic stem cell lines harboring various mutations in APC, a crucial member of the $\beta$-catenin degradation complex (Kielman et al. 2002). By controlling the dose of $\beta$-catenin signaling through altering its degradation, a relation between differentiation and Wnt signaling surfaced in totipotent stem cells that was far more complex than a simple on or off switch. The picture emerging from these studies is that the outcome of Wnt signaling depends on the expression profile of the recipient cell.

Strong evidence for a role of Wnt signaling in stem cell maintenance comes from gene targeting of Tcf4. Mice lacking Tcf4 die shortly after birth, and seem unable to generate or maintain intestinal stem cells (Korinek et al. 1998). In the intestine, $\beta$-catenin/Tcf 4 signaling seems to function at least in part by regulating expression of EphrinB1 and its receptors, as mice lacking intestinal ephrin receptors display marked perturbations in the organization of stem cells and their progeny in this tissue (Batlle et al. 2002). The loss of the stem cell population in Tcf4null intestine, combined with a possible defect in cell positioning, raises the question of whether stem cells lose access to their niche and differentiate because of loss of local cues to maintain a stem cell fate.

Other roles for Wnt signaling in cell fate determination include the inhibition of preadipocyte differentiation to adipocytes (Ross et al. 2000) and neural differentiation in the retina (Kubo et al. 2003), and the promotion of hematopoietic cell fate decisions (Lako et al. 2001), neural crest early migration (Hari et al. 2002), and 
specification of neurons in the dorsal spinal cord (Muroyama et al. 2002). Given that many of these findings have emerged in the past few years, it seems likely that our understanding of the role of Wnts in stem cell maintenance and determination will grow in the future.

\section{Concluding remarks}

As scientists struggle to learn how stem cells maintain themselves while repopulating complex tissues in normal homeostasis as well as injury repair, the public is eager for treatments for deadly or debilitating diseases. Adult stem cells may have tremendous therapeutic potential, and the skin epithelium represents an enormous source of accessible stem cells that might be a starting point for generating cells to replace diseased tissue. Organ transplantation without immunosuppression is only one possible result. Skin stem cells have already been used to replace skin lost to burns; whether it will be possible to use skin stem cell plasticity to engineer treatments for other disorders remains to be determined. Although increasing evidence supports a role for Wnt signaling in skin epithelial stem cell maintenance and/or determination, deregulated Wnt signaling activation has long been implicated in human cancers. As carcinogenesis is associated with dedifferentiation, mechanisms discovered in cancer biology could prove useful in enticing partially differentiated stem cells of one lineage down alternative cell fate pathways. When scientists can control precisely the degree of Wnt signal a cell receives, as well as the expression of other pathway members such as Lef/Tcf family members, stem cell therapeutics may be closer to reality.

\section{Acknowledgments}

We thank our many colleagues in the field, as well as past and present Fuchs' lab researchers, who have helped to define a role for Wnt signaling in skin stem cells and their lineages. E.F. is an Investigator of the Howard Hughes Medical Institute. The research leading to this review was supported by a grant from the National Institutes of Health (R01-AR31737).

\section{References}

Andl, T., Reddy, S.T., Gaddapara, T., and Millar, S.E. 2002. WNT signals are required for the initiation of hair follicle development. Dev. Cell 2: 643-653.

Arnold, I. and Watt, F.M. 2001. c-Myc activation in transgenic mouse epidermis results in mobilization of stem cells and differentiation of their progeny. Curr. Biol. 11: 558-568.

Baker, J.C., Beddington, R.S., and Harland, R.M. 1999. Wnt signaling in Xenopus embryos inhibits bmp4 expression and activates neural development. Genes \& Dev. 13: 3149-3159.

Barrandon, Y. and Green, H. 1987. Three clonal types of keratinocyte with different capacities for multiplication. Proc. Natl. Acad. Sci. 84: 2302-2306.

Batlle, E., Henderson, J.T., Beghtel, H., van den Born, M.M., Sancho, E., Huls, G., Meeldijk, J., Robertson, J., van de Wetering, M., Pawson, T., et al. 2002. $\beta$-Catenin and TCF mediate cell positioning in the intestinal epithelium by controlling the expression of EphB/ephrinB. Cell 111: 251-263.
Bjornson, C.R., Rietze, R.L., Reynolds, B.A., Magli, M.C., and Vescovi, A.L. 1999. Turning brain into blood: A hematopoietic fate adopted by adult neural stem cells in vivo. Science 283: 534-537.

Botchkarev, V.A., Botchkareva, N.V., Roth, W., Nakamura, M., Chen, L.H., Herzog, W., Lindner, G., McMahon, J.A., Peters, C., Lauster, R., et al. 1999. Noggin is a mesenchymally derived stimulator of hair-follicle induction. Nat. Cell Biol. 1: $158-164$.

Brabletz, T., Jung, A., Dag, S., Hlubek, F., and Kirchner, T. 1999. $\beta$-Catenin regulates the expression of the matrix metalloproteinase-7 in human colorectal cancer. Am. I. Pathol. 155: 1033-1038.

Brakebusch, C., Grose, R., Quondamatteo, F., Ramirez, A., Jorcano, J.L., Pirro, A., Svensson, M., Herken, R., Sasaki, T., Timpl, R., et al. 2000. Skin and hair follicle integrity is crucially dependent on $\beta 1$ integrin expression on keratinocytes. EMBO J. 19: 3990-4003.

Chan, E.F., Gat, U., McNiff, J.M., and Fuchs, E. 1999. A common human skin tumour is caused by activating mutations in $\beta$-catenin. Nat. Genet. 21: 410-413.

Chan, S.K. and Struhl, G. 2002. Evidence that Armadillo transduces wingless by mediating nuclear export or cytosolic activation of Pangolin. Cell 111: 265-280.

Chiang, C., Swan, R.Z., Grachtchouk, M., Bolinger, M., Litingtung, Y., Robertson, E.K., Cooper, M.K., Gaffield, W., Westphal, H., Beachy, P.A., et al. 1999. Essential role for Sonic hedgehog during hair follicle morphogenesis. Dev. Biol. 205: 1-9.

Cotsarelis, G., Sun, T.T., and Lavker, R.M. 1990. Label-retaining cells reside in the bulge area of pilosebaceous unit: Implications for follicular stem cells, hair cycle, and skin carcinogenesis. Cell 61: 1329-1337.

Crowe, R., Henrique, D., Ish-Horowicz, D., and Niswander, L. 1998. A new role for Notch and Delta in cell fate decisions: Patterning the feather array. Development 125: 767-775.

Daniels, D.L. and Weis, W.I. 2002. ICAT inhibits $\beta$-catenin binding to Tcf/Lef-family transcription factors and the general coactivator p300 using independent structural modules. Mol. Cell 10: 573-584.

DasGupta, R. and Fuchs, E. 1999. Multiple roles for activated LEF/TCF transcription complexes during hair follicle development and differentiation. Development 126: 4557-4568.

Ferrari, G., Cusella-De Angelis, G., Coletta, M., Paolucci, E., Stornaiuolo, A., Cossu, G., and Mavilio, F. 1998. Muscle regeneration by bone marrow-derived myogenic progenitors. Science 279: 1528-1530.

Fuchs, E. and Cleveland, D.W. 1998. A structural scaffolding of intermediate filaments in health and disease. Science 279: 514-519.

Fuchs, E., Merrill, B.J., Jamora, C., and DasGupta, R. 2001. At the roots of a never-ending cycle. Dev. Cell 1: 13-25.

Gandarillas, A. and Watt, F.M. 1997. c-Myc promotes differentiation of human epidermal stem cells. Genes \& Dev. 11: 2869-2882.

Gat, U., DasGupta, R., Degenstein, L., and Fuchs, E. 1998. De novo hair follicle morphogenesis and hair tumors in mice expressing a truncated $\beta$-catenin in skin. Cell 95: 605-614.

Green, H. 1991. Cultured cells for the treatment of disease. Sci. Am. 265: 96-102.

Gussoni, E., Soneoka, Y., Strickland, C.D., Buzney, E.A., Khan, M.K., Flint, A.F., Kunkel, L.M., and Mulligan, R.C. 1999. Dystrophin expression in the mdx mouse restored by stem cell transplantation. Nature 401: 390-394.

Hardy, M.H. 1992. The secret life of the hair follicle. Trends Genet. 8: 55-61. 
Hari, L., Brault, V., Kleber, M., Lee, H.Y., Ille, F., Leimeroth, R., Paratore, C., Suter, U., Kemler, R., and Sommer, L. 2002. Lineage-specific requirements of $\beta$-catenin in neural crest development. J. Cell Biol. 159: 867-880.

He, T.C., Sparks, A.B., Rago, C., Hermeking, H., Zawel, L., da Costa, L.T., Morin, P.J., Vogelstein, B., and Kinzler, K.W. 1998. Identification of c-MYC as a target of the APC pathway. Science 281: 1509-1512.

Headon, D.J., Emmal, S.A., Ferguson, B.M., Tucker, A.S., Justice, M.J., Sharpe, P.T., Zonana, J., and Overbeek, P.A. 2001. Gene defect in ectodermal dysplasia implicates a death domain adapter in development. Nature 414: 913-916.

Huelsken, J., Vogel, R., Erdmann, B., Cotsarelis, G., and Birchmeier, W. 2001. $\beta$-Catenin controls hair follicle morphogenesis and stem cell differentiation in the skin. Cell 105: 533545.

Ivanova, N.B., Dimos, J.T., Schaniel, C., Hackney, J.A., Moore, K.A., and Lemischka, I.R. 2002. A stem cell molecular signature. Science 298: 601-604.

Jahoda, C.A., Horne, K.A., and Oliver, R.F. 1984. Induction of hair growth by implantation of cultured dermal papilla cells. Nature 311: 560-562.

Jamora, C., DasGupta, R., Kocieniewski, P., and Fuchs, E. 2003. Links between signal transduction, transcription and adhesion in epithelial bud development. Nature 422: 317-322.

Jensen, U.B., Lowell, S., and Watt, F.M. 1999. The spatial relationship between stem cells and their progeny in the basal layer of human epidermis: A new view based on wholemount labelling and lineage analysis. Development 126: 2 409-2418.

Jiang, Y., Jahagirdar, B.N., Reinhardt, R.L., Schwartz, R.E., Keene, C.D., Ortiz-Gonzalez, X.R., Reyes, M., Lenvik, T., Lund, T., Blackstad, M., et al. 2002. Pluripotency of mesenchymal stem cells derived from adult marrow. Nature 418: 41-49.

Jones, P.H. and Watt, F.M. 1993. Separation of human epidermal stem cells from transit amplifying cells on the basis of differences in integrin function and expression. Cell 73: 713-724.

Jones, P.H., Harper, S., and Watt, F.M. 1995. Stem cell patterning and fate in human epidermis. Cell 80: 83-93.

Jung, H.S., Francis-West, P.H., Widelitz, R.B., Jiang, T.X., TingBerreth, S., Tickle, C., Wolpert, L., and Chuong, C.M. 1998. Local inhibitory action of BMPs and their relationships with activators in feather formation: Implications for periodic patterning. Dev. Biol. 196: 11-23.

Kalinin, A.E., Kajava, A.V., and Steinert, P.M. 2002. Epithelial barrier function: Assembly and structural features of the cornified cell envelope. Bioessays 24: 789-800.

Kaur, P. and Li, A. 2000. Adhesive properties of human basal epidermal cells: An analysis of keratinocyte stem cells, transit amplifying cells, and postmitotic differentiating cells. $J$. Invest. Dermatol. 114: 413-420.

Kawakami, Y., Capdevila, J., Buscher, D., Itoh, T., Rodriguez Esteban, C., and Izpisua Belmonte, J.C. 2001. WNT signals control FGF-dependent limb initiation and AER induction in the chick embryo. Cell 104: 891-900.

Kielman, M.F., Rindapaa, M., Gaspar, C., van Poppel, N., Breukel, C., van Leeuwen, S., Taketo, M.M., Roberts, S., Smits, R., and Fodde, R. 2002. APC modulates embryonic stem-cell differentiation by controlling the dosage of $\beta$-catenin signaling. Nat. Genet. 32: 594-605.

Kishimoto, J., Burgeson, R.E., and Morgan, B.A. 2000. Wnt signaling maintains the hair-inducing activity of the dermal papilla. Genes \& Dev. 14: 1181-1185.

Knoblich, J.A. 2001. Asymmetric cell division during animal development. Nat. Rev. Mol. Cell. Biol. 2: 11-20.
Kobayashi, K. and Nishimura, E. 1989. Ectopic growth of mouse whiskers from implanted lengths of plucked vibrissa follicles. J. Invest. Dermatol. 92: 278-282.

Kobayashi, K., Rochat, A., and Barrandon, Y. 1993. Segregation of keratinocyte colony-forming cells in the bulge of the rat vibrissa. Proc. Nat1. Acad. Sci. 90: 7391-7395.

Kolodka, T.M., Garlick, J.A., and Taichman, L.B. 1998. Evidence for keratinocyte stem cells in vitro: Long term engraftment and persistence of transgene expression from retrovirus-transduced keratinocytes. Proc. Natl. Acad. Sci. 95: 4356-4361.

Kong, J., Li, X.J., Gavin, D., Jiang, Y., and Li, Y.C. 2002. Targeted expression of human vitamin $\mathrm{D}$ receptor in the skin promotes the initiation of the postnatal hair follicle cycle and rescues the alopecia in vitamin $\mathrm{D}$ receptor null mice. J. Invest. Dermatol. 118: 631-638.

Kopan, R. and Fuchs, E. 1989. A new look into an old problem: Keratins as tools to investigate determination, morphogenesis, and differentiation in skin. Genes \& Dev. 3: 1-15.

Korinek, V., Barker, N., Moerer, P., van Donselaar, E., Huls, G., Peters, P.J., and Clevers, H. 1998. Depletion of epithelial stem-cell compartments in the small intestine of mice lacking Tcf-4. Nat. Genet. 19: 379-383.

Kowalczyk, A.P., Bornslaeger, E.A., Norvell, S.M., Palka, H.L., and Green, K.J. 1999. Desmosomes: Intercellular adhesive junctions specialized for attachment of intermediate filaments. Int. Rev. Cytol. 185: 237-302.

Kratochwil, K., Dull, M., Farinas, I., Galceran, J., and Grosschedl, R. 1996. Lef1 expression is activated by BMP-4 and regulates inductive tissue interactions in tooth and hair development. Genes \& Dev. 10: 1382-1394.

Kratochwil, K., Galceran, J., Tontsch, S., Roth, W., and Grosschedl, R. 2002. FGF4, a direct target of LEF1 and Wnt signaling, can rescue the arrest of tooth organogenesis in Lef1 $1^{-/}$ mice. Genes \& Dev. 16: 3173-3185.

Krause, D.S., Theise, N.D., Collector, M.I., Henegariu, O., Hwang, S., Gardner, R., Neutzel, S., and Sharkis, S.J. 2001. Multi-organ, multi-lineage engraftment by a single bone marrow-derived stem cell. Cell 105: 369-377.

Kubo, F., Takeichi, M., and Nakagawa, S. 2003. Wnt2b controls retinal cell differentiation at the ciliary marginal zone. Development 130: 587-598.

LaBarge, M.A. and Blau, H.M. 2002. Biological progression from adult bone marrow to mononucleate muscle stem cell to multinucleate muscle fiber in response to injury. Cell 111: 589-601.

Labbe, E., Letamendia, A., and Attisano, L. 2000. Association of Smads with lymphoid enhancer binding factor $1 / \mathrm{T}$ cell-specific factor mediates cooperative signaling by the transforming growth factor- $\beta$ and Wnt pathways. Proc. Natl. Acad. Sci. 97: 8358-8363.

Lako, M., Lindsay, S., Lincoln, J., Cairns, P.M., Armstrong, L., and Hole, N. 2001. Characterisation of Wnt gene expression during the differentiation of murine embryonic stem cells in vitro: Role of Wnt3 in enhancing haematopoietic differentiation. Mech. Dev. 103: 49-59.

Laurikkala, J., Pispa, J., Jung, H.S., Nieminen, P., Mikkola, M., Wang, X., Saarialho-Kere, U., Galceran, J., Grosschedl, R., and Thesleff, I. 2002. Regulation of hair follicle development by the TNF signal ectodysplasin and its receptor Edar. Development 129: 2541-2553.

Le Borgne, R., Bellaiche, Y., and Schweisguth, F. 2002. Drosophila E-cadherin regulates the orientation of asymmetric cell division in the sensory organ lineage. Curr. Biol. 12: 95104.

Li, A., Simmons, P.J., and Kaur, P. 1998. Identification and iso- 
lation of candidate human keratinocyte stem cells based on cell surface phenotype. Proc. Natl. Acad. Sci. 95: 3902-3907. Li, B., Mackay, D.R., Dai, Q., Li, T.W., Nair, M., Fallahi, M., Schonbaum, C.P., Fantes, J., Mahowald, A.P., Waterman, M.L., et al. 2002. The LEF1/ $\beta$-catenin complex activates movol, a mouse homolog of Drosophila ovo required for epidermal appendage differentiation. Proc. Natl. Acad. Sci. 99: 6064-6069.

Li, M., Chiba, H., Warot, X., Messaddeq, N., Gerard, C., Chambon, P., and Metzger, D. 2001. RXR- $\alpha$ ablation in skin keratinocytes results in alopecia and epidermal alterations. Development 128: 675-688.

Lowell, S., Jones, P., Le Roux, I., Dunne, J., and Watt, F.M. 2000. Stimulation of human epidermal differentiation by DeltaNotch signalling at the boundaries of stem-cell clusters. Curr. Biol. 10: 491-500.

Lu, B., Roegiers, F., Jan, L.Y., and Jan, Y.N. 2001. Adherens junctions inhibit asymmetric division in the Drosophila epithelium. Nature 409: 522-525.

Mackenzie, I.C. 1997. Retroviral transduction of murine epidermal stem cells demonstrates clonal units of epidermal structure. J. Invest. Dermatol. 109: 377-383.

Merrill, B.J., Gat, U., DasGupta, R., and Fuchs, E. 2001. Tcf3 and Lef1 regulate lineage differentiation of multipotent stem cells in skin. Genes \& Dev. 15: 1688-1705.

Mezey, E., Chandross, K.J., Harta, G., Maki, R.A., and McKercher, S.R. 2000. Turning blood into brain: Cells bearing neuronal antigens generated in vivo from bone marrow. Science 290: 1779-1782.

Mill, P., Mo, R., Fu, H., Grachtchouk, M., Kim, P.C., Dlugosz, A.A., and Hui, C.C. 2003. Sonic hedgehog-dependent activation of Gli2 is essential for embryonic hair follicle development. Genes \& Dev. 17: 282-294.

Millar, S.E., Willert, K., Salinas, P.C., Roelink, H., Nusse, R., Sussman, D.J., and Barsh, G.S. 1999. WNT signaling in the control of hair growth and structure. Dev. Biol. 207: 133-149.

Mills, A.A., Zheng, B., Wang, X.J., Vogel, H., Roop, D.R., and Bradley, A. 1999. p63 is a p53 homologue required for limb and epidermal morphogenesis. Nature 398: 708-713.

Molenaar, M., van de Wetering, M., Oosterwegel, M., PetersonMaduro, J., Godsave, S., Korinek, V., Roose, J., Destree, O., and Clevers, H. 1996. XTcf-3 transcription factor mediates $\beta$-catenin-induced axis formation in Xenopus embryos. Cell 86: 391-399.

Morris, R.J. and Potten, C.S. 1994. Slowly cycling (label-retaining) epidermal cells behave like clonogenic stem cells in vitro. Cell Prolif. 27: 279-289.

- 1999. Highly persistent label-retaining cells in the hair follicles of mice and their fate following induction of anagen. J. Invest. Dermatol. 112: 470-475.

Muroyama, Y., Fujihara, M., Ikeya, M., Kondoh, H., and Takada, S. 2002. Wnt signaling plays an essential role in neuronal specification of the dorsal spinal cord. Genes \& Dev. 16: $548-553$.

Niemann, C., Owens, D.M., Hulsken, J., Birchmeier, W., and Watt, F.M. 2002. Expression of $\Delta$ NLef1 in mouse epidermis results in differentiation of hair follicles into squamous epidermal cysts and formation of skin tumours. Development 129: 95-109.

Nishita, M., Hashimoto, M.K., Ogata, S., Laurent, M.N., Ueno, N., Shibuya, H., and Cho, K.W. 2000. Interaction between Wnt and TGF- $\beta$ signalling pathways during formation of Spemann's organizer. Nature 403: 781-785.

Noramly, S. and Morgan, B.A. 1998. BMPs mediate lateral inhibition at successive stages in feather tract development. Development 125: 3775-3787.
Nusse, R. 1999. WNT targets. Repression and activation. Trends Genet. 15: 1-3.

Oliver, R.F. 1969. The vibrissa dermal papilla and its influence on epidermal tissues. Br. J. Dermatol. 81: 55-65.

Oshima, H., Rochat, A., Kedzia, C., Kobayashi, K., and Barrandon, Y. 2001. Morphogenesis and renewal of hair follicles from adult multipotent stem cells. Cell 104: 233-245.

Panteleyev, A.A., Botchkareva, N.V., Sundberg, J.P., Christiano, A.M., and Paus, R. 1999. The role of the hairless (hr) gene in the regulation of hair follicle catagen transformation. Am. J. Pathol. 155: 159-171.

Pellegrini, G., Dellambra, E., Golisano, O., Martinelli, E., Fantozzi, I., Bondanza, S., Ponzin, D., McKeon, F., and De Luca, M. 2001. p63 identifies keratinocyte stem cells. Proc. Nat1. Acad. Sci. 98: 3156-3161.

Peterson, D.A. 2002. Stem cells in brain plasticity and repair. Curr. Opin. Pharmacol. 2: 34-42.

Pokutta, S. and Weis, W.I. 2002. The cytoplasmic face of cell contact sites. Curr. Opin. Struct. Biol. 12: 255-262.

Potten, C.S. 1974. The epidermal proliferative unit: The possible role of the central basal cell. Cell Tissue Kinet. 7: 77-88.

Potten, C.S. and Morris, R.J. 1988. Epithelial stem cells in vivo. J. Cell Sci. Suppl. 10: 45-62.

Potten, C.S., Schofield, R., and Lajtha, L.G. 1979. A comparison of cell replacement in bone marrow, testis and three regions of surface epithelium. Biochim. Biophys. Acta 560: 281-299.

Povelones, M. and Nusse, R. 2002. Wnt signalling sees spots. Nat. Cell Biol. 4: E249-E250.

Raghavan, S., Bauer, C., Mundschau, G., Li, Q., and Fuchs, E. 2000. Conditional ablation of $\beta 1$ integrin in skin. Severe defects in epidermal proliferation, basement membrane formation, and hair follicle invagination. I. Cell Biol. 150: 1149-1160.

Ramalho-Santos, M., Yoon, S., Matsuzaki, Y., Mulligan, R.C., and Melton, D.A. 2002. 'Stemness': Transcriptional profiling of embryonic and adult stem cells. Science 298: 597-600.

Reddy, S., Andl, T., Bagasra, A., Lu, M.M., Epstein, D.J., Morrisey, E.E., and Millar, S.E. 2001. Characterization of Wnt gene expression in developing and postnatal hair follicles and identification of Wnt5a as a target of Sonic hedgehog in hair follicle morphogenesis. Mech. Dev. 107: 69-82.

Reya, T., Morrison, S.J., Clarke, M.F., and Weissman, I.L. 2001. Stem cells, cancer, and cancer stem cells. Nature 414: 105 111.

Rheinwald, J.G. and Green, H. 1975. Serial cultivation of strains of human epidermal keratinocytes: The formation of keratinizing colonies from single cells. Cell 6: 331-343.

- 1977. Epidermal growth factor and the multiplication of cultured human epidermal keratinocytes. Nature 265: 421424.

Riese, J., Yu, X., Munnerlyn, A., Eresh, S., Hsu, S.C., Grosschedl, R., and Bienz, M. 1997. LEF-1, a nuclear factor coordinating signaling inputs from wingless and decapentaplegic. Cell 88: 777-787.

Rochat, A., Kobayashi, K., and Barrandon, Y. 1994. Location of stem cells of human hair follicles by clonal analysis. Cell 76: $1063-1073$.

Ross, S.E., Hemati, N., Longo, K.A., Bennett, C.N., Lucas, P.C., Erickson, R.L., and MacDougald, O.A. 2000. Inhibition of adipogenesis by Wnt signaling. Science 289: 950-953.

Segre, J.A., Bauer, C., and Fuchs, E. 1999. Klf4 is a transcription factor required for establishing the barrier function of the skin. Nat. Genet. 22: 356-360.

Song, X. and Xie, T. 2002. DE-cadherin-mediated cell adhesion is essential for maintaining somatic stem cells in the Drosophila ovary. Proc. Natl. Acad. Sci. 99: 14813-14818. 
St-Jacques, B., Dassule, H.R., Karavanova, I., Botchkarev, V.A., Li, J., Danielian, P.S., McMahon, J.A., Lewis, P.M., Paus, R., and McMahon, A.P. 1998. Sonic hedgehog signaling is essential for hair development. Curr. Biol. 8: 1058-1068.

Tani, H., Morris, R.J., and Kaur, P. 2000. Enrichment for murine keratinocyte stem cells based on cell surface phenotype. Proc. Natl. Acad. Sci. 97: 10960-10965.

Taylor, G., Lehrer, M.S., Jensen, P.J., Sun, T.T., and Lavker, R.M. 2000. Involvement of follicular stem cells in forming not only the follicle but also the epidermis. Cell 102: 451461.

Terada, N., Hamazaki, T., Oka, M., Hoki, M., Mastalerz, D.M., Nakano, Y., Meyer, E.M., Morel, L., Petersen, B.E., and Scott, E.W. 2002. Bone marrow cells adopt the phenotype of other cells by spontaneous cell fusion. Nature 416: 542-545.

Tetsu, O. and McCormick, F. 1999. $\beta$-Catenin regulates expression of cyclin D1 in colon carcinoma cells. Nature 398: 422426.

Travis, A., Amsterdam, A., Belanger, C., and Grosschedl, R. 1991. LEF-1, a gene encoding a lymphoid-specific protein with an HMG domain, regulates T-cell receptor $\alpha$ enhancer function. Genes \& Dev. 5: 880-894.

Tutter, A.V., Fryer, C.J., and Jones, K.A. 2001. Chromatin-specific regulation of LEF- $1-\beta$-catenin transcription activation and inhibition in vitro. Genes \& Dev. 15: 3342-3354.

van de Wetering, M., Oosterwegel, M., Dooijes, D., and Clevers, H. 1991. Identification and cloning of TCF-1, a T lymphocyte-specific transcription factor containing a sequence-specific HMG box. EMBO I. 10: 123-132.

van Genderen, C., Okamura, R.M., Farinas, I., Quo, R.G., Parslow, T.G., Bruhn, L., and Grosschedl, R. 1994. Development of several organs that require inductive epithelial-mesenchymal interactions is impaired in LEF-1-deficient mice. Genes \& Dev. 8: 2691-2703.

Viallet, J.P., Prin, F., Olivera-Martinez, I., Hirsinger, E., Pourquie, O., and Dhouailly, D. 1998. Chick Delta-1 gene expression and the formation of the feather primordia. Mech. Dev. 72: 159-168.

Wagers, A.J., Sherwood, R.I., Christensen, J.L., and Weissman, I.L. 2002. Little evidence for developmental plasticity of adult hematopoietic stem cells. Science 297: 2256-2259.

Waikel, R.L., Kawachi, Y., Waikel, P.A., Wang, X.J., and Roop, D.R. 2001. Deregulated expression of c-Myc depletes epidermal stem cells. Nat. Genet. 28: 165-168.

Wang, L.C., Liu, Z.Y., Gambardella, L., Delacour, A., Shapiro, R., Yang, J., Sizing, I., Rayhorn, P., Garber, E.A., Benjamin, C.D., et al. 2000. Regular articles: Conditional disruption of hedgehog signaling pathway defines its critical role in hair development and regeneration. I. Invest. Dermatol. 114: 901-908.

Waterman, M.L., Fischer, W.H., and Jones, K.A. 1991. A thymus-specific member of the HMG protein family regulates the human $\mathrm{T}$ cell receptor $\mathrm{C} \alpha$ enhancer. Genes \& Dev. 5: 656-669.

Watt, F.M. 1998. Epidermal stem cells: Markers, patterning and the control of stem cell fate. Philos. Trans. R Soc. Lond. $B$ Biol. Sci. 353: 831-837.

Weimann, J.M., Charlton, C.A., Brazelton, T.R., Hackman, R.C., and Blau, H.M. 2003. Contribution of transplanted bone marrow cells to Purkinje neurons in human adult brains. Proc. Natl. Acad. Sci. 7: 7.

Yang, A., Schweitzer, R., Sun, D., Kaghad, M., Walker, N., Bronson, R.T., Tabin, C., Sharpe, A., Caput, D., Crum, C., et al. 1999. p63 is essential for regenerative proliferation in limb, craniofacial and epithelial development. Nature 398: 714718.
Ying, Q.L., Nichols, J., Evans, E.P., and Smith, A.G. 2002. Changing potency by spontaneous fusion. Nature 416: 545548.

Zhou, P., Byrne, C., Jacobs, J., and Fuchs, E. 1995. Lymphoid enhancer factor 1 directs hair follicle patterning and epithelial cell fate. Genes \& Dev. 9: 700-713.

Zorn, A.M., Barish, G.D., Williams, B.O., Lavender, P., Klymkowsky, M.W., and Varmus, H.E. 1999. Regulation of Wnt signaling by Sox proteins: XSox $17 \alpha / \beta$ and XSox3 physically interact with $\beta$-catenin. Mol. Cell 4: 487-498. 


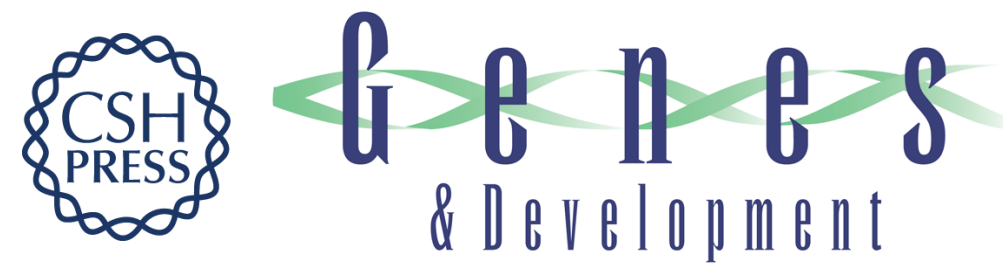

\section{Stem cells in the skin: waste not, Wnt not}

Laura Alonso and Elaine Fuchs

Genes Dev. 2003, 17:

Access the most recent version at doi:10.1101/gad.1086903

References This article cites 116 articles, 42 of which can be accessed free at: http://genesdev.cshlp.org/content/17/10/1189.full.html\#ref-list-1

License

Email Alerting Receive free email alerts when new articles cite this article - sign up in the box at the top Service right corner of the article or click here.

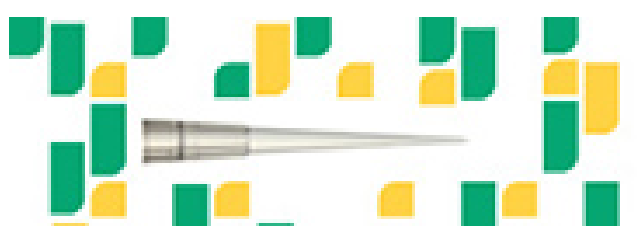

Focused on your science. 